\title{
LADANG HITAM PASCA PERISTIWA GERAKAN 30 SEPTEMBER 1965 (Studi Kasus Tragedi Kemanusiaan Anggota PKI di Desa Penglatan, Kecamatan Buleleng, Kabupaten Buleleng, Provinsi Bali dan Potensinya Sebagai Sumber Belajar Sejarah Kontenporer Indonesia)
}

\author{
Ketut Sedana Arta, Desak Made Oka Purnawati, Made Pageh \\ Jurusan Pendidikan Sejarah, Fakultas Hukum dan IImu Sosial, Universitas \\ Pendidikan Ganesha, Singaraja, Indonesia \\ sedana.arta@gmail.com
}

\begin{abstract}
Abstrak
Secara umum tujuan penelitian ini adalah (1)untuk mengetahui latar belakang peristiwa tragedi kemanusiaan pasca peristiwa Gerakan 30 September 1965 di Desa Penglatan; (2) untuk menganalisis proses tragedi kemanusiaan pasca peristiwa Gerakan 30 September 1965 di Desa Penglatan;(3) untuk menganalisis implikasi tragedi kemanusiaan pasca peristiwa Gerakan 30 September 1965 di Desa Penglatan: (4) untuk mengetahui aspek-aspek dari tragedi kemanusiaan pasca peristiwa Gerakan 30 September 1965 di Desa Penglatan yang dapat dijadikan sebagai sumber belajar

Penelitian ini secara metodologis menggunakan pendekatan kualitatif, teknik penentuan informan dengan purposive sampling dan informan terus dikembangkan dengan teknik snowball. Dalam pengumpulan data peneliti menggunakan: (1) Wawancara; (2) Observasi partisipasi Agar observasi partisipasi bisa terarah, maka ditetapkan aspek-aspek yang diobservasi; (3) Analisis dokumen

Hasil penelitian ini menunjukkan bahwa latar belakang peristiwa tragedi kemanusiaan pasca peristiwa Gerakan 30 September 1965 di Desa Penglatan adalah 1). Adanya persaingan politik, persaingan tersebut berakar dari persaingan antara PNI dan PKI yang embrionya dimulai sejak tahun 1955, (2) Proses tragedi kemanusiaan pasca peristiwa Gerakan 30 September 1965 di Desa Penglatan terjadi beberapa minggu setelah kudeta tahun 1965 (Gestok, I Oktober 1965), melibatkan organisasi sayap partai dari PNI meliputi GSNI, PETANI, LKN, GPM, GPD, serta ormas yang tergabung dalam PKI seperti BTI, Lekra, maupun Pemuda Rakyat. (3) Implikasi tragedi kemanusiaan pasca peristiwa Gerakan 30 September 1965 bagi desa dan keluarga di Desa Penglatan adalah membawa dampak yang luas bagi keluarga yang ditinggalkan, dampak yang paling dirasakan adalah rasa trauma simpatisan dan pengurus PKI. Keluarga-keluarga kehilangan tulang punggung keluarga, dan dirasakan dampaknya merekapun mendapatkan perlakuan diskriminatif, seperti adanya kode ET, yang berarti eks tahanan politik; (4) Aspek-aspek dari tragedi kemanusiaan pasca peristiwa Gerakan 30 September 1965 di Desa Penglatan 1) Aspek Historis, yang dapat
\end{abstract}


dijadikan sebagai sumber belajar sejarah kontemporer Tragedi kemanusiaan dengan terbunuhnya beberapa pengurus PKI dan simpatisan PKI (Pemuda Rakyat).2) Kolaborasi Pembunuhan Anggota PKI, yang melibatkan kekuasaan Pepelrada Bali Pangdam XVI/Udayana, serta RPKAD

Kata kunci: Gerakan 30 September, tragedi kemanusiaan, sumber belajar sejarah

\section{Abstract}

In general the purpose of this study is (1) to know the background events of human tragedy after the events of the Movement of 30 September 1965 in Penglatan Village; (2) to analyze the process of human tragedy after the events of the 30 September 1965 Movement in Penglatan Village; (3) to analyze the implications of humanitarian tragedy after the events of the 30 September 1965 Movement in Penglatan Village: (4) to know aspects of the humanitarian tragedy after the Movement September 30, 1965 in Penglatan Village which can be used as a learning resource

This research methodologically using qualitative approach, informative determination technique with purposive sampling and informant continue to be developed with snowball technique. In collecting data researchers use: (1) Interviews; (2) Observation of participation In order for participant observation to be directed, the observed aspects are stipulated; (3) Document analysis

The results of this study indicate that the background events of human tragedy after the events of the Movement of 30 September 1965 in Penglatan Village is 1). The existence of political competition, the competition is rooted in the rivalry between the PNI and the PKI, whose embryo began in 1955, (2) The process of human tragedy after the September 30, 1965 Movement in Penglatan Village occurred several weeks after the 1965 coup (Gestok, I October 1965) Involving party wing organizations from the PNI including GSNI, PETANI, LKN, GPM, GPD, and mass organizations belonging to the PKI such as BTI, Lekra, and Pemuda Rakyat. (3) The implications of humanitarian tragedy after the events of the September 30th Movement of 1965 for villages and families in Penglatan Village were to have a wide impact on abandoned families, the most perceived impact was the trauma of sympathizers and administrators of the PKI. Families lose the backbone of the family, and feel their effects are subject to discriminatory treatment, such as the existence of the ET code, which means former political prisoners; (4) Aspects of the humanitarian tragedy after the events of the September 30th Movement of 1965 in Penglatan Village 1) The historical aspect, which can be used as a source of contemporary history learning The tragedy of humanity with the killing of several PKI officials and sympathizers 
of the PKI (Pemuda Rakyat) .2) Collaborative Murders Members of the PKI, involving the power of Pepelrada Bali Pangdam XVI / Udayana, and RPKAD

Keywords: September 30th Movement, humanitarian tragedy, historical learning resource

\section{PENDAHULUAN}

Bali adalah daerah yang dikenal sebagai pulau dewata, seribu pura, dan masyarakat diikat oleh simpul-simpul budaya Bali diantara desa pekraman, subak, sekeha dan dilandasi ideologi $T r i$ Hita Karana. Menurut Wiana (2007:125) Pemujaan terhadap Tuhan Yang Maha Esa dalam konsep Tri Hita Karana disamping membangun sikap hidup memelihara kesejahteraan alam juga menumbuhkan hubungan yang harmonis dalam kehidupan bersaama dalam suatu masyarakat. Mengacu pada gagasan Atmadja (2014) untuk mewujudkan harmonisasi dalam suatu masyarakat maka perlu ada pelembagaan teoekologi. Gagasan ini bertumpu pada pemikiran bahwa alam, manusia, Tuhan (Brahman) merupakan satu kesaatuan yang tidak bisa terpisahkan. Selain itu masyarakat Bali juga lekat dengan ajaran Tat Twam Asi (itu adalah kamu). Konsep ini melahirkan jargon Vasudhaiva Kutumbakham (semua makhluk adalah bersaudara. Gagasan ini membawa implikasi menyakiti makhluk hidup yang lain sama artinya menyakiti saudara sendiri.

Masyarakat Bali juga diikat oleh ajaran agama Hindu yaitu ahimsa atau nirkekerasan, yakni doktrin yang melarang manusia melakukan kekerasan terhadap makhluk lain dalam pikiran, ucapan dan tindakan guna mewujudkan kedamaian. Ahimsa berkaitan dengan Tat Twam Asi yang melahirkan gagasan bahwa kita bersaudara. Karena kita bersaudara maka kita harus welas asih yang sekaligus berarti ahimsa terhadap semua makhluk. Dengan demikian ahimsa adalah intisari kasih dan sifat manusia (Sing, 2007:89)

Simpul-simpul budaya Bali yang dilandasi ajaran agama Hindu tersebut nampaknya diabaikan karena perbedaanperbedaan politik dalam sejarah masyarakat Bali. Hal ini Nampak dari adanya politik kekerasan yang terjadi pasca peristiwa 30 September yang memakan korban tidak sedikit. Menurut Galtung kekerasan dapat didefinisikan sebagai penyebab perbedaan antara yang potensial dan yang actual. Kekerasan yang terjadi pada masa itu berwujud kekerasan fisik sampai penghilangan nyawa dan kekerasan psikologis, yakni kekerasan terhadap jiwa dan rohani. menurut Semelin (2003) hal ini bisa disebut kekerasan yang tidak nampak.

Pada masa awal kemerdekaan PKI kembali muncul sebagai kekuatan politik yang patut diperhitungkan dengan datangnya kembali para pemimpin yang di tahan di Boven Digul, Eksistensi PKI dimungkinkan dengan cara menempuh sikap moderat dengan mendukung pemerintah bernegosiasi dengan Belanda. Konpensasinya PKI mendapat jatah anggota Parlemen dari 2 orang menjadi 35 orang. Eksistensi PKI tidak bisa dilepaskan dari peran dari Nyoto, Aidit dan Lukman yang membangun sekaligus menata ulang organisasi PKI setelah compang-camping terimbas meletusnya Peristiwa Madiun tahun 1948. Mereka 
meluncurkan dokumen Djalan Baru untuk Memenangkan Revolusi. dalam kepemimpinan PKI baru, Aidit menjabat Sekjen, MH Lukman Wakil Sekjen, dan Njoto Wakil Sekjen II (Julius Pour, 2010: 22).

Pembunuhan-pembunuhan

terhadap anggota PKI dan simpatisan PKI dilatarbelakangi oleh kekerasan yang terjadi antara dua partai besar di Bali yaitu PNI dan PKI dan pembekuan aktivitas PKI dan organisasi-organisasi yang berafiliasi dengan PKI, serta adanya penahanan terhadap pendukung PKI dan penyusunan daftar anggota PKI dan organisasi masanya. Pertentangan antara PKI dan PNI terjadi sejak diberlakukannya Demokrasi Terpimpin yang dicerminkan dari aksi-aksi massa seperti rapat umum politik, defile dan demonstrasi dikelola $\mathrm{PKI} / \mathrm{BTI}$ maupun PNI/Petani (Robinson, 1995: 269-270). Aksi-aksi masa tersebut disertai dengan ungkapan-ungkapan yang saling menjelekan antar partai dalam pidato-pidato partai politik (Vickers, 1989: 169; H. Geertz, 1991: 180-182). Di tempattempat di mana sebagian besar pembantaian terjadi memang sudah ada ketegangan selama bertahun-tahun karena program land reform yang merujuk pada UU Agraria 1960, yang didukung dan dilaksanakan oleh PKI dan organisasiorganisasi front PKI. Ini terjadi di Jawa tengah, Jawa Timur, Sumatera Utara, dan Bali (Jusuf Wanandi, 2014:91)

Proses terjadinya tragedi kemanusiaan ini tidak bisa lepas dari peran negara, kususnya keterlibatan Angkatan Darat dalam pembunuhanpembunuhan yang terjadi dengan menyediakan dukungan logistic seperti transportasi, daftar orang yang dibunuh, latihan bahkan senjata, dan dorongan semangat kepada kelompok-kelompok paramiliter sebagai pelaku tindak kekerasan di lapangan, namun sebagian besar pembunuhan-pembunuhan yang sebenarnya diserahkan pada rakyat biasa (Frans Husken, 2003; Budi Susanto, 2003: 24)

Dampak dari peristiwa tragedi
kemanusiaan pasca Gerakan 30 September 1965 menimbulkan trauma dalam berbegai segi kehidupan terutama mereka yang berasal dari keluarga korban tragedi tersebut. Peristiwa ini merupakan pelanggaran Hak Azasi Manusia yang diperkuat dari pengumuman laporan Komnas HAM tentang tragedi 65 di Jakarta, 23 Juli 2012 (Baskara. T Wardaya, 2014:2). Penelitian ini dapat memperkaya materi bahwa pasca peristiwa Gerakan 30 September 1965 tragedi kemanusiaan tidak hanya terjadi di Jawa tetapi terjadi juga di Kabupaten Buleleng, khususnya di tingkat desa yang latar belakang, proses dan implikasinya sangat menarik untuk dikaji. Dengan adanya sumber-sumber materi sejarah lokal diharapkan penanaman nilai-nilai sejarah sejarah melalui proses pendidikan bersifat ekstrensik tetapi juga pencapaian nilai intinsik yang membentuk intelektual yang kritis dan rasional (Abdullah, 1996; Widja 1996)

\section{METODE}

Penelitian ini menggunakan pendekatan kualitatif, yang teknik penentuan informannya menggunakan purposive sampling. Adapun teknik pengumpulan datanya menggunakan wawancara mendalam terhadap tokohtokoh yang terlibat langsung dalam peristiwa tragedi kemanusiaan anggota PKI di Desa Penglatan, dan diperkuat dengan observasi tempat tragedi kemanusiaan tersebut terjadi, serta 
menganalisis dokumen-dokumen untuk memperkuat analisis kejadian. Untuk menjamin kesahihan data maka dilakukan trianggulasi data. Sedangkan teknik analisis datanya menggunakan model interaktif yang meliputi reduksi data, penyajian data, penafsiran data, dan menarik kesimpulan.

\section{HASIL DAN PEMBAHASAN}

\section{A. Hasil Penelitian}

1. latar belakang peristiwa tragedi kemanusiaan pasca peristiwa Gerakan 30 September 1965 di Desa Penglatan

Berdasarkan wawncara dengan tokoh PNI di Desa Penglatan tragedi kemanusiaan yang terjadi dilatarbelakangi adanya persaingan politik antara PNI dan $\mathrm{PKI}$ yang embrionya dimulai ketika pemilu 1955 yang dimenangkan oleh PNI, sementara di Bali PKI menjadi partai pemenang ke dua. kekerasan yang terjadi di Indonesia saat itu dilakukan dengan menggunakan senjata tajam seperti pisau, clurit, maupun pedang, tetapi juga menggunakan senjata tumpul seperti pentungan, tongkat dan alat kekerasan lainnya serta menggunakan senjata api.

Berdasarkan wawancara dan observasi di lapangan tempat terjadinya eksekusi adalah seme atau kuburan desa setelah penjemputan secara paksa yang teridentifikasi sebagai anggota dan simpatisan PKI oleh masa PNI. Menurut Hermawan Sulistyo (2000:204) pada tingkat pelaku pembataian di lapangan tidak terdapat struktur jaringan yang ketat, bahkan cenderung longgar.

Menurut Wayan Renten dan Wayan Sedana (wawancara tanggal 22 Agustus 2016) menyatakan persaingan politik di tingkat pusat tercermin pula di tingkat akar rumput terutama di Desa Penglatan.
Masing-masing penguru partai membentuk kepengurusan di tingkat ranting. Untuk PNI pengurus di tingkat ranting dipimpin oleh I Wayan Darpa, dan PKI dipimpin oleh Bapak Nurita. Persaingan politik di Desa Penglatan melibatkan kubu nasionalis (PNI) dan kubu komunis (PKI) merambah juga pada persaingan di bidang ekonomi.

\section{Proses tragedi kemanusiaan pasca peristiwa Gerakan 30 September 1965 di Desa Penglatan}

Berdasarkan hasil wawancara dengan narasumber pasca peristiwa Gestok (Gerakan 31 September 1965) sebenarnya keadaan tidaklah segawat seperti yang ada di Jakarta sebagai barometer perpolitikan nasional. Keadaan tersebut berubah ketika ada instruksi dari petinggi Angkatan Darat untuk melaksanakan kebijakan tumpas kelor.

Angkatan darat memainkan peran penting dalam mendukung awal terjadinya pembantaian, dengan kesatuan RPKAD yang mendarat di Bali pada 7-8 Desember 1965, menyebarkan daftar hitam anggota PKI yang harus dibunuh. Angkatan Darat juga merangkul dan melatih gerombolan milisi, para pemuda sipil yang disebut tameng untuk menguasai teknik-teknik dasar membantai. Para pemuda PNI yang tergabung dalam Gerakan Siswa Nasional Indonesia (GSNI), PETANI (Persatuan Petani Nasional Indonesia), LKN (Lembaga Kebudayaan Nasional), Gerakan Pendidik Marhaenis, Gerakan Pemuda Demokrat secara aktif ikut dalam usaha-usaha pendataan anggota-anggota PKI yang terganung dalam BTI dan Lekra maupun Pemuda Rakyat

\section{Implikasi tragedi kemanusiaan pasca peristiwa Gerakan 30}


September 1965 bagi desa dan keluarga di Desa Penglatan

Dampak yang dirasakan oleh anggota PKI di Desa Penglatan adalah trauma yang mendalam. Keluarga yang ditinggal juga mendapat sanksi sosial dari masyarakat di lingkungan desa, mereka dicap sebagai keturunan $\mathrm{PKI}$, setiap aktivitas mereka selalu mendapat pengawasan dari aparat warga, aparat desa dan pihak berwajib. Dalam pelayanan administrasi pasca peristiwa $G$ 30 September 1965, merekapun mendapatkan perlakuan diskriminatif, seperti adanya kode ET, yang berarti eks tahanan politik, dan mereka tidak dapat melamar kerja diinstansi pemerintah karena adanya litsus.

Trauma mendalam yang dialami oleh penduduk pasca pembersihan terhadap anggota PKI, menyebabkan mereka mencari kedamaian melalui ajaran-ajaran kerohanian seperti mengikuti acara-acara pesantian dengan sumbersumber seperti Bhagawad Githa, Arjuna Wiwaha, Ramayana, Sucita.

\section{Aspek-aspek tragedi kemanusiaan pasca peristiwa Gerakan 30 September 1965 yang dapat dijadikansebagai pembelajaran sejarah sumber}

1) Aspek Historis, Tragedi kemanusiaan dengan terbunuhnya beberapa pengurus PKI dan simpatisan PKI (Pemuda Rakyat) yang dapat dijadikan sebagai sumber belajar sejarah kontemporer. Buku-buku sejarah yang memuat peristiwa pasca gerakan 30 September 1965 atau di Bali dikenal sebagai Gestok, hanya memuat peristiwa yang ada di Jakarta, sedikit yang membahas daerah-daerah lainnya.Untuk Bali Pasca peristiwa Gestok di Bali, sebenarnya awalnya aman-aman saja, tetapi ketika gaung penumpasan PKI di Jawa tengah dan Jawa Timur terdengar di Bali, timbul ketegangan-ketegangan antara masa PKI dan PNI termasuk di Desa Penglatan. $\mathrm{PKI}$

2) Kolaborasi Pembunuhan Anggota

Tanggal 17 November 1965, kekuasaan Pepelrada Bali Pangdam $\mathrm{XVI} /$ Udayana yang sebelumnya dipegang oleh Gubernur Bali Anak Agung bagus Sutedja. Pepelrada juga mengeluarkan keputusan pada tanggal 24 November 1965 tentang pedoman untuk menumpas G $30 \mathrm{~S} / \mathrm{PKI}$ dan kewenangan TIM Pemerintah Daerah (Teperda) dalam memeriksa oknum-oknum yang terlibat $G$ $30 \mathrm{~S} / \mathrm{PKI}$. Salah satu strategi yang ditempuh di Bali oleh RPKAD dalam upayanya melaksanakan tugas menumpas PKI di Bali adalah dalam bentuk mengendalikan dan memfasilitasi ekseskusi terhadap yang dicurigai sebagai komunis dengan penyediaan dukungan logistik yang penting berupa senjata, amunisi, truk, komunikasi, dan fasilitas penahanan. Militer juga mendorong gerombolan satgas keamanan anti PKI bersenjata. Yang paling menonjol dan paling ditakuti adalah tameng marhaenis yang disokong PNI, kawanan beranggotakan delapan atau sepuluh orang yang berkeliaran dalam busana hitam-hitam, bersenjatakan belati, tombak dan bedil.

\section{B. PEMBAHASAN}

1. Latar belakang peristiwa tragedi kemanusiaan pasca peristiwa Gerakan 30 September 1965 di Desa Penglatan

Tindak kekerasan politik dan politik kekerasan yang kadang kala terjadi dalam skala massif, tampak menjadi warna yang 
paling dominan selama berlangsungnya praktek politik rezim Orde Baru. Tampilnya kekuatan politik Orde Baru menggantikan rezim politik Demokrasi terpimpin di panggung politik Indonesia ditandai dengan proses berlangsungnya tindakan yang menafikan nilai-nilai kemanusiaan, berupa pembantaian terhadap paling tidak puluhan ribu orang-orang yang tergabung dalam organisasi komunis selama kurun waktu 1965-1966. Kendati demikian, proses pembersihan terhadap orang-orang Komunis di Bali dan Khususnya desa-desa di Bali Utara tidak berhenti pada tahuntahun tersebut, karena kekerasan secara psikologis sebagai anak PKI terus dilabelkan pada orang-orang yang pernah tergabung dalam organisasi PKI.

Secara lebih rinci latar belakang tragedi kemanusiaan di Desa Penglatan, Kecamatan Buleleng, Kabupaten Buleleng dapat dirinci sebagai berikut:

\section{Persaingan Politik}

Menurut hasil wawancara dengan Wayan Sedana tokoh PNI di Desa Penglatan, persaingan politik tersebut di Desa Penglatan terjadi antara PNI dan PKI yang memiliki basis kuat diakar rumput. Persaingan kedua partai tersebut bahkan mulai terjadi ketika ada pemilu tahun 1955. Walaupun PNI unggul dalam perolehan suara namun PKI juga memperoleh suara yang tidak bisa diremehkan.

Kuatnya PNI di Swapraja Buleleng disebabkan oleh beberapa faktor. Pertama, dekatnya PNI dengan Bung Karno yang secara geneologis namanya sangat harum di mata rakyat Buleleng karena memiliki orang tua dari garis ibu yang berasal dari banjar Paket Agung Singaraja. Disamping itu, Bung Karno dengan ajarannya terutama Marhaenisme dan Pancasila telah mempengaruhi tokohtokoh di Buleleng. Kedua, duduknya orang-orang $\mathrm{PNI}$ di pemerintahan mempermudah PNI menyampaikan program-programnya kepada masyarakat, dan adanya kesamaan program PNI dengan pemerintah. Ketiga, adanya dukungan rakyat di luar pemerintah, terutama mantan pejuang revolusi 1945, para pejuang mempunyai pengaruh besar bagi PNI dalam memenangkan pemilu 1955. Peranan Ketut Widjana dari Penataran, Singaraja, Nyoman gde Mangku dari Jagaraga, Nengah Sari dari Desa Sekumpul mempunyai andil besar dalam proses pengembangan $\mathrm{PNI}$ di Buleleng. Keempat,PNI dengan asas sosionasionalisme dan sosiodemokrasi bertujuan untuk menampung dan memperjuangkan kepentingan rakyat, tanpa membedakan suku, agama, dan pelapisan dalam masyarakat. Kelima, situasi pemilu dengan menggunakan demokrasi liberal, sistem ini memungkinkan masyarakat betul-betul bebas memilih partai sesuai dengan aspirasinya. Keenam, partisipasi masyarakat, khususnya di Kabupaten Buleleng cukup tinggi. Ini membuka peluang bagi PNI untuk memperoleh dukungan . Pada pemilu 1955, di Kabupaten Buleleng tercatat 144.838 orang pemilih, dengan suara sah sebanyak 127.467. Jadi partisipasi politik masyarakat Buleleng pada tahun 1955 adalah 88\% (Budiasih, 1992:75-79)

Menurut Wayan Renten (wawancara tanggal 22 Agustus 2016) menyatakan persaingan politik di tingkat pusat tercermin pula di tingkat akar rumput terutama di Desa Penglatan. Masingmasing penguru partai membentuk kepengurusan di tingkat ranting. Untuk PNI pengurus di tingkat ranting dipimpin oleh I Wayan Darpa, dan PKI dipimpin oleh Bapak Nurita. Untuk memperkuat 
basis masa masing-masing partai mengadakan konsolidasi partai dalam bentuk rapat-rapat partai, menonjolkan simbol-simbol partai seperti pada saat pertemuan PKI mereka sering menyanyikan lagu-lagu PKI seperti genjergenjer, sedangkan PNI memakai symbolsimbol seperti lambing kebesaran PNI kepala banteng dalam segitiga pada peralatan pertanian mereka, langkah ini diikuti oleh $\mathrm{PKI}$ dengan menyertakan symbol-simbol PKI (Palu arit) pada peralatan pertanian anggota $\mathrm{PKI}$.

Nuansa persaingan politik di tingkat pedesaan juga tidak bisa dilepaskan situasi politik di tingkat nasional, dengan adanya selogan semangat revolusi belum berakhir yang terus dikobarkan oleh Presiden Sukarno membawa implikasi pada lahirnya proses radikalisme massa dan mobilisasi politik. Berpangkal keadaan ini berbagai kekuatan politik merasa mendapat legitimasi dalam rangka melakukan tindakan yang bersifat revolusioner. Mereka menjalankan peran pencarian dukungan massa dalam rangka jor-joran Manipol. Yang kemudian terjadi adalah bukan sekadar petunjuk dari meningkatnya politisasi dan mobilisasi politik serta radikalisme masa. Lebih disayangkan juga melahirkan proses kehidupan bermasyarakat, berbangsa dan bernegara yang menonjolkan identitas social baik itu agama, ideology, suku maupun kelompok. Implikasi yang kemudian harus diterima adalah terdapatnya konflik ideology secara terbuka antarkekuatan politik (Ignas Cleden, 1998:30)

\section{Persaingan Ekonomi}

Persaingan politik di Desa Penglatan melibatkan kubu nasionalis (PNI) dan kubu komunis (PKI) merambah juga pada persaingan di bidang ekonomi.
Penuturan I Wayan Renten memberikan gambaran anggota $\mathrm{PKI}$ yang memiliki aktivitas ekonomi seperti berdagang, maka anggota PNI tidak mau berbelanja keanggota PKI, demikian juga sebaliknya, demikian pula pada saat musim panen petani PKI (BTI) tidak mau meseke dengan petani yang berpartai PNI yang dibuktikan dengan symbol-simbol partai pada alat-alat pertanian mereka.

Perkembangan PKI yang demikian pesat membuat khawatir kalangan kaum kanan, hal tersebut diakui oleh pimpinan PNI seperti Wayan Darpa, Wayan Sedana, Wayan Renten, Gusti Putu Teken. Diperhitungkan, kalau berlangsung pemilihan umum, PKI akan mencapai kemenangan besar, bahkan kedudukan presiden bisa direbut oleh PKI. Maka untuk mencegah terjadinya hal tersebut, pihak Angkatan Darat mengusulkan penundaan Pemilihan Umum, dan A.H Nasution mengajukan gagasan presiden seumur hidup, agar wakil PKI tidak bisa merebut kedudukan ini. Gagasan ini diajukan pada Suwirjo (Ketua PNI) yang mendukung gagasan ini. Maka diusulkan Bung Karno jadi presiden seumur hidup melalui ketetapan MPRS Nomor III/MPRS/1963.

Berkembangnya PKI di desa-desa termasuk di Desa Penglatan tidak bisa dilepaskan focus PKI yang menggarap masa dari kaum tani. Seperti yang dikemukakan oleh Suar Suroso (2013:210) bahwa Aidit sampai-sampai harus mengadakan riset ke desa-desa dengan praktek tiga sama yakni sama bekerja, sama makan, dan sama tidur. Dalam risetnya Aidit di tahun 1964 menyimpulkan bahwa maha pentingnya kaum tani atau desa dalam revolusi.

Program yang ditawarkan oleh oleh pimpinan pusat $\mathrm{PKI}$ ditambah dengan 
gerakan PKI untuk kembali ke desa, telah mampu meningkatkan anggota PKI yang berbasis sebagai petani. Program turun ke bawah sebuah kampanye untuk menguatkan kader-kader partai di perkotaan besar maupun kecil agar pergi ke desa-desa, mengakrabkan diri dengan kondisi-kondisi setempat, dan mendidik kaum tani dalam kebijakan dan program tani, program ini juga dimaksudkan dalam rangka menanggulangi kurangnya jumlah aktivis di desa-desa yang memahami tujuan-tujuan partai dan bersedia mewujudkannya menghadapi perlawanan para pemuka tinggi desa. Hal tersebut dibenarkan oleh mantan ketua ranting PKI desa Penglatan bernama Ketut Nurita bahwa keikutsertaan penduduk desa dalam organisasi PKI karena programprogram partai yang ditawarkan dan juga karena pemerintah menjamin kebebasan dalam berpartai serta diakuinya PKI sebagai partai yang sah di Desa Penglatan. Pendapat tersebut diperkuat oleh Suar Suroso (2013:195) bahwa PKI diakui sebagai salah satu partai yang sah berdasarkan Keputusan Presiden RI No. 123/1961. Dengan adanya PKI yang memiliki basis masa besar di Penglatan, maka terdapat beberapa partai yang besar seperti PNI, PKI dan Partindo.

Perekrutan dan pendidikan aktivisaktivis PKI di tingkat desa dimaksudkan untuk memenangkan kepercayaan kaum tani. Gerakan kembali ke desa mengalami beberapa hambatan antara lain keterbelakangan ekonomi dan tingkat pendidikan yang masih rendah sehingga memerlukan kerja keras dalam rangka menanamkan nilai ideology partai. Para aktivis yang telah mendapatkan pendidikan kaderisasi diberikan instruksi tidak boleh melakukan gerakan apapun tanpa persiapan mendalam sehingga untuk mengadakan kampanye aksi, pertama-tama usulan itu harus didiskusikan dan disetujui terlebih dahulu oleh organisasi partai di tingkat desa, lalu meminta kesepakatan organisasi petani di skala nasional (BTI). Meski prosedur untuk sebuah aksi cukup ketat dan panjang, namun yang penting adalah jika kepercayaan para petani sudah bisa diciptakan aksi-aksi ke depan tentunya akan berjalan sukses. Namun keteganganketegangan akibat perbedaan partai cukup terasa di Desa Penglatan, gambaran tersebut dikemukakan oleh I Wayan Renten mantan sekdes Desa Penglatan yang menginformasikan bahwa masingmasing anggota partai baik PNI maupun PKI membekali diri dengan senjata tajan seperti pedang dan tidak lupa juga membekali diri dengan ilmu kebal.

\section{Proses tragedi kemanusiaan pasca peristiwa Gerakan 30 September 1965 di Desa Penglatan}

Berdasarkan hasil wawancara dengan narasumber pasca peristiwa Gestok (Gerakan 31 September 1965) sebenarnya keadaan tidaklah segawat seperti yang ada di Jakarta sebagai barometer perpolitikan nasional. Keadaan tersebut berubah ketika ada instruksi dari petinggi Angkatan Darat. Kebijakan tumpas kelor (menghabisi hingga ke akarakarnya sudah diawali sejak bulan Oktober 1965. hal ini diawali oleh pernyataan Jendral Abdul Haris Nasution setelah pemakaman para Jendral yang terbunuh tanggal 1 Oktober 1965 bahwa PKI harus dibasmi sampai keakar-akarnya dan kampanya bahwa PKI merupakan dalang dari $G 30$ S yang telah dimulai sejak 1 Oktober 1965 oleh harian militer Angkatan Bersenjata dan berita Yudha yang diizinkan terbit 1-8 Oktober 1965. 
Pada tanggal 17 Oktober 1965, pasukan para Komando Angkatan Darat di bawah pimpinan Kolonel Sarwo Edhie Wibowo, diperintahkan berangkat ke Jawa Tengah untuk membersihkan keterpecahan pasukan di provinsi itu akibat ketidakpercayaan sebagian besar anggota Divisi Diponogoro terhadap pusat. Pembasmian Komunis dan sekutusekutunya dimulai di Jawa Tengah dan dengan cepat menyebar ke Jawa Timur dan provinsi-provinsi lainnya. Sebagian besar berita yang masuk menyetujui Angkatan Darat yang memulai pembantaian masal rakyat Indonesia beberapa bulan kemudian, namun dibanyak tempat termasuk di Bali Angkatan darat tidak bekerja sendirian melainkan dibantu kelompok-kelompok pemuda yang anti Komunis yang menjadi eksekutor di lapangan termasuk di Desa Penglatan

Angkatan darat memainkan peran penting dalam mendukung awal terjadinya pembantaian, dengan kesatuan RPKAD yang mendarat di Bali pada 7-8 Desember 1965, menyebarkan daftar hitam anggota PKI yang harus dibunuh. Angkatan Darat juga merangkul dan melatih gerombolan milisi, para pemuda sipil yang disebut tameng untuk menguasai teknik-teknik dasar membantai. tetapi orang-orang Bali melampaui instruktur mereka dengan menyerang anggota PKI dengan keganasan yang sangat mengerikan. Pendapat tersebut dibenarkan oleh Suryawan (2007) yang mendeskripsikan militer mendorong kelompok-kelompok pemuda untuk mengambil peran aktif dalam proses pembantaian ini. Kelompok yang paling beringas adalah Tameng Marhaenis (PNI). Menurut tokoh PNI Penglatan kelompok ini menyasar rumah anggota PKI pada malam hari, berpakaian hitam dan bercadar, menandai rumah, dan membakar rumah, beranggotakan 10-15 orang, sasarannya tidak hanya PKI dalam satu desa bisa pula menyasar anggota PKI di luar desa.

Ada kenyataan berbeda proses terjadinya pembantaian anggota PKI di Desa Penglatan, terutama Banjar Kajanan dan Banjar Kelodan. Khusus untuk banjar Kelodan anggota PKI yang terbunuh sebanyak tiga orang, berbeda dengan Banjar Kajanan yang tewas sebanyak 17 orang, diantaranya Caklik, Loka, Loso, Genah, Jimat, sedangkan banjar Kelodan jumlah korban hanya tiga orang, yaitu Nyoman Swica, Ketut Koyan, Men Biji. Khusus untuk kasus men Biji terpaksa dibunuh karena mempunyai ilmu Black Magic (IImu Hitam/Pengeleakan). Men Biji beradu ilmu dengan tokoh PNI bernama I Dayuh yang berprofesi sebagai dukun di Desa Penglatan. Menurut informan yang diwawancarai I Dayuh mengajarkan ilmu aliran kanan tetapi yang diajarkan berbau Islam, karena dalam proses pembelajaran yang diajarkan kepada murid-muridnya menggunakan rerajahan huruf arab. Beliau pernah melakukan perang tanding kekuatan ilmu dengan Men Biji yang konon bisa mengubah wujudnya menjadi rangda. Menurut I Wayan Renten perang tanding antara Bape Dayuh dan Men Biji dimenangkan oleh Bape Dayuh, konon kuku rangda penjelmaan Men Biji berhasil dipotong. Masa yang marah mencari Men Biji di rumah banjar Dauh Tukad, di bawah bantalnya ditemukan sabuk pengeleakan yang sangat panjang. Selanjutnya Men Biji diarak keliling banjar adat, dan dibunuh di kuburan Banjar Adat Kelodan oleh pasukan Tameng PNI. Nyoman Swica, Ketut Koyan dibunuh oleh Sibang, Neca, dan Merta. 
Kuburan Banjar Adat kelodan juga sebagai tempat eksekusi anggota PKI dari Desa Silangjana sebanyak 9 orang, namun pihak aparat desa Penglatan tidak tahu identitas orang-orang tersebut, selain dari Silangjana ada tiga korban pembunuhan anggota PKI dari Tenaon yang terdiri dari Konod, Garwa, Sriya. Orang-orang dari Desa Tenaon tersebut tersebut secara psikologis sangat tertekan hal tersebut pernyataan tumben menek motor jani mati sube.

Pasukan Tameng PNI yang berseragam hitam-hitam mempunyai andil besar dalam usaha pembasmian orangorang PKI baik di Desa Penglatan maupun desa-desa lainnya, mereka bekerjasama dengan anggota tameng PNI dari Desa Penarungan, Jinangdalem, Alasangker. dalam melaksanakan tugasnya anggota Tameng PNI memakai sandi-sandi yang hanya bisa dimengerti oleh anggotanya, seperti penggunaan sandi Mawar harus dibalas Sandat, Karung harus dijawab Ember, Serang dijawab Diam. Kalau balasan sandi benar maka orang yang diajak berhadap-hadapan itu adalah teman dari Tameng PNI, kalau salah berarti adalah musuh. Masing-masing anggota Tameng PNI sudah terbagi dalam tugas masing-masing, ada yang mengintai, membawa minyak gas, ada yang mengekseskusi rumah yang menjadi anggota $\mathrm{PKI}$, sementara penghuni rumah pasrah menyerahkan diri, ada yang dieksekusi di tempat, dibawa ke kuburan desa ada yang dibawa ke kuburan desa lainnya seperti di Banjar Adat Kelodan serta ada di bawa ke seme sakit di Yeh Taluh.

Anggota PKI di Banjar Kelodan yang terbunuh hanya 3 orang disebabkan adanya rasa belas kasihan dari anggota PNI yang masih terikat oleh pertalian darah seperti saudara kandung, memisan, keponakan, dan tunggal dadia. Kebanyakan anggota PKI di Kelodan diamankan di rumah pengurus ranting $\mathrm{PKI}$ untuk mendapat perlindungan sampai keadaan aman, dalam hal ini ada hutang budi anggota $\mathrm{PKI}$ yang tidak terbunuh kepada pengurus PNI.

Untuk Banjar Kajanan anggota PKI yang terbunuh sebanyak 17 Orang, mereka dikategorikan simpatisan PKI, pengurus $\mathrm{PKI}$, dan orang-orang yang dituduh sebagai anggota PKI. menurut I Wayan Sedana, mereka terbunuh selain karena perbedaan ideologi partai juga disebabkan karena adanya sentimen pribadi, anggota PKI di Banjar kajanan dieksekusi di seme Banjar Kajanan, berbeda halnya dengan warga kelodan yang masih terikat rasa kekeluargaan. Untuk banjar dauh Tukad yang meninggal adalah Swindra, Swenten, Windra, Budana. Keadaan pembunuhan terhadap tokoh PKI bernama Swindra sangat kejam, hal tersebut berdasarkan penuturan I Wayan Sedana aktivis PNI yang menceritakan bahwa tubuh I wayan Windra diseret di jalan raya dari Banyuning Selatan sampai Perempatan Banyuning Selatan, tubuhnya berdarahdarah sampai menghembuskan napasnya

3. Implikasi tragedi kemanusiaan pasca peristiwa Gerakan 30 September 1965 bagi desa dan keluarga di Desa Penglatan

\section{Trauma Mendalam}

Tragedi kemanusiaan yang terjadi di Desa penglatan membawa dampak yang luas bagi keluarga yang ditinggalkan, dampak yang paling dirasakan adalah rasa trauma, banyak diantara keluarga yang ditanya peneliti tidak ingin menceritakan bagaimana kisah dari 
peristiwa pembunuhan terhadap keluarga mereka yang dulu menjadi simpatisan dan pengurus $\mathrm{PKI}$. Keluarga-keluarga kehilangan tulang punggung keluarga, dan dirasakan dampaknya secara ekonomi.

Keluarga yang ditinggal juga mendapat sanksi sosial dari masyarakat di lingkungan desa, mereka dicap sebagai keturunan PKI, setiap aktivitas mereka selalu mendapat pengawasan dari aparat warga, aparat desa dan pihak berwajib. Dalam pelayanan administrasi pasca peristiwa G 30 September 1965, merekapun mendapatkan perlakuan diskriminatif, seperti adanya kode ET, yang berarti eks tahanan politik, dan mereka tidak dapat melamar kerja diinstansi pemerintah.Litsus : Penelitian Khusus, sebuah proses seleksi untuk meneliti calon anggota legislatif yang diajukan partai politik. Diterapkan pada masa orde baru untuk menghindari calon yang berafiliasi paham komunis dan meyakinkan bahwa calon memiliki sifat monoloyalitas. Pada akhirnya listsus dipakai untuk menyingkirkan tokoh yang bersebrangan dengan pemerintah dan menghegemoni sikap kritis anggota DPR.

\section{Mencari kedamaian rohani}

Trauma mendalam yang dialami oleh penduduk pasca pembersihan terhadap anggota PKI, menyebabkan mereka mencari kedamaian melalui ajaran-ajaran kerohanian seperti mengikuti acara-acara pesantian dengan sumbersumber seperti Bhagawad Githa, Arjuna Wiwaha, Ramayana, Sucita. Dalam perkembangannya mereka mendapat bimbingan ajaran agama Budha. Bimbingan kerohanian ini mampu menarik minat eks anggota PKI untuk memeluk agama Budha. Bersama-sama dengan penduduk dari Desa Alasangker, Petandakan yang mempunyai nasib sama secara tekun mendengarkan kotbah di sela-sela pesantian yang acaranya di malam hari, sehingga oleh masyarakat yang kurang bersimpati kelompok kerohanian ini mendapat julukan sebagai PKI malam.

\section{Kemiskinan}

Setelah terjadi pemberontakan $G$ $30 \mathrm{~S} / \mathrm{PKI}$ (gestok), banyak anggota PKI dan simpatisannya terbunuh akibat penumpasan, keadaan tersebut juga dialami anggota keluarga yang tergabung dalam kelompok megeguritan, karena keanggotaan dalam PKI dan Partindo. Mereka kehilangan orang tua, saudara, pekerjaan yang berimplikasi terhadap sosial perekonomian. Anggota keluargakeluarga yang ditinggal harus menanggung beban ekonomi yang berat. Krisis ekonomi memang mereka alami sebelum peristiwa G $30 \mathrm{~S} / \mathrm{PKI}$ dan berlanjut hingga awal tahun 1970-an.

4. Aspek-aspek tragedi kemanusiaan pasca peristiwa Gerakan 30 September 1965 yang dapat dijadikansebagai sumber pembelajaran sejarah

\section{Aspek Historis}

Tragedi kemanusiaan dengan terbunuhnya beberapa pengurus PKI dan simpatisan PKI (Pemuda Rakyat) bisa dijadikan sumber belajar terutama pada matakuliah sejarah Indonesia IV atau dikenal juga sebagai mata kuliah sejarah Kontenporer Indonesia. Buku-buku sejarah yang memuat peristiwa pasca gerakan 30 September 1965 atau di Bali dikenal sebagai Gestok, hanya memuat peristiwa yang ada di Jakarta, sedikit yang membahas daerah-daerah lainnya.Untuk Bali Pasca peristiwa Gestok di Bali, sebenarnya awalnya aman-aman saja, tetapi ketika gaung penumpasan PKI di Jawa tengah dan Jawa Timur terdengar di Bali, timbul ketegangan-ketegangan 
antara masa $\mathrm{PKI}$ dan $\mathrm{PNI}$ termasuk di Desa Penglatan.

Dalam buku-buku sejarah dijelaskan Pembantaian 1965-1966, yang menjadi korban adalah orang-orang yang menjadi bagian dari PKI serta orang-orang yang dituduh sebagai komunis. Meski banyak spekulasi menyebut, si anu dan si anu, namun dalang di balik pembantaian massal itu hingga kini masih belum dirilis secara resmi. Pembantaian di Indonesia 1965-1966 adalah peristiwa pembantaian terhadap orang-orang yang dituduh komunis di Indonesia pada masa setelah terjadinya Gerakan 30 September di Indonesia. Diperkirakan lebih dari setengah juta orang dibantai dan lebih dari satu juta orang dipenjara dalam peristiwa tersebut.

Pembersihan ini merupakan peristiwa penting dalam masa transisi ke Orde Baru, Partai Komunis Indonesia (PKI) dihancurkan, pergolakan mengakibatkan jatuhnya presiden Soekarno, dan kekuasaan selanjutnya diserahkan kepada Soeharto. Kudeta yang gagal menimbulkan kebencian terhadap komunis karena kesalahan dituduhkan kepada PKI. Komunisme dibersihkan dari kehidupan politik, sosial, dan militer, dan PKI dinyatakan sebagai partai terlarang. Pembantaian dimulai pada Oktober 1965 dan memuncak selama sisa tahun sebelum akhirnya mereda pada awal tahun 1966. Pembersihan dimulai dari ibu kota Jakarta, yang kemudian menyebar ke Jawa Tengah dan Timur, lalu Bali. Ribuan vigilante (orang yang menegakkan hukum dengan caranya sendiri) dan tentara angkatan darat menangkap dan membunuh orang-orang yang dituduh sebagai anggota PKI. Meskipun pembantaian terjadi di seluruh Indonesia, namun pembantaian terburuk terjadi di

benteng-benteng PKI di Jawa Tengah, Timur, Bali, dan Sumatera Utara. Pembantaian ini hampir tidak pernah disebutkan dalam buku sejarah Indonesia, dan hanya memperoleh sedikit perhatian dari orang Indonesia maupun warga internasional.

Secara umum di Bali, sepanjang Oktober dan November 1965, timbul ketegangan politik yang serius kampanye anti PKI tidak mengakibatkan pembunuhan besar-besaran di Bali. Selama Oktober dan medio November 1965, gempuran terhadap PKI di Bali pada umumnya berbentuk pembersihan politik di pelbagai jawatan pemerintahan, universitas, dan organisasi politik, selain kehilangan pekerjaan, para korban pembersihan ini diwajibkan melapor ke pihak berwenang militer, dengan kemungkinan dikenai penahanan tanpa tuduhan formal atau proses pengadilan. Mereka yang melapor juga diwajibkan membawa daftar anggota lain PKI dan organisasi massanya, sehingga menyediakan sarana untuk pembersihan yang lebih sistematis di kemudian hari. Hal sama dialami oleh Pak Mawit (mantan ketua ranting PKI Desa Penglatan) yang mengatakan dirinya pernah dipanggil tentara dan disuruh untuk menyerahkan nama-nama yang termasuk anggota PKI, beliau tidak terbunuh karena dianggap sangat kooperatif dengan pihak keamanan, padahal istrinya Ketut Puspa sudah memberikan tirta pengentas dan mengiklaskan kepergiannya, namun nasib berkehendak lain, beliau masih hidup dengan anak-anak yang sudah sukses hidupnya, bahkan ada anaknya yang menjadi pegawai negeri.

\section{Kolaborasi Pembunuhan \\ Anggota PKI}


Tanggal 17 November 1965, kekuasaan Pepelrada Bali Pangdam $\mathrm{XVI} /$ Udayana yang sebelumnya dipegang oleh Gubernur Bali Anak Agung bagus Sutedja. Pepelrada juga mengeluarkan keputusan pada tanggal 24 November 1965 tentang pedoman untuk menumpas G 30 S/PKI dan kewenangan TIM Pemerintah Daerah (Teperda) dalam memeriksa oknum-oknum yang terlibat $\mathrm{G}$ 30 S/PKI (Sarwa, 1985:71-72)

Salah satu strategi yang ditempuh di Bali oleh RPKAD dalam upayanya melaksanakan tugas menumpas PKI di Bali adalah dalam bentuk mengendalikan dan memfasilitasi ekseskusi terhadap yang dicurigai sebagai komunis dengan penyediaan dukungan logistik yang penting berupa senjata, amunisi, truk, komunikasi, dan fasilitas penahanan. Pada sejumlah kasus, eksekusi massal tidak mungkin terjadi tanpa dukungan semacam ini. Militer juga mendorong gerombolan satgas keamanan anti PKI bersenjata. Yang paling menonjol dan paling ditakuti adalah tameng marhaenis yang disokong PNI, kawanan beranggotakan delapan atau sepuluh orang yang berkeliaran dalam busana hitam-hitam, bersenjatakan belati, tombak dan bedil. Kasus yang terjadi di Desa Penglatan sama dengan yang terjadi di desa-desa lainnya di Buleleng, namun dengan korban lebih sedikit, karena kuatnya ikatan tali persaudaraan dalam tunggal dadia.

Partai-partai, khususnya PNI, juga membina gagasan bahwa kampanye menentang PKI adalah perang suci sehingga menopengi kuatnya unsur-unsu oportunisme politik dan pembalasan yang memotivasi banyak pemimpin dan anggotanya. Suryawan (2010:514) menyatakan bahwa pembunuhan terhadap anggota dan simpatisan PKI tidak dipandang oleh pembunuhnya sendiri sebagai perbuatan criminal atau tindakan politik. kalau orang Bali ditanya apa yang membuat mereka ikut dalam pembunuhan itu, jawabanya pasti selalu sama, yakni demi memenuhi kewajiban religious untuk menyucikan pulau.

PNI Cabang Buleleng membagi empat wilayah kerja sehubungan dengan upaya penumpasan PKI. Di wilayah Buleleng Timur meliputi wilayah Tejakula, Kubutambahan, dan Sawan yang operasinya dipimpin oleh Nyoman Gede Mangku selaku Kepala Staf Komando Wilayah Buleleng Timur. Nyoman Gede Mangku adalah mantan ketua IV PNI Cabang Buleleng kelahiran Desa Jagaraga, Kecamatan Sawan, seorang tokoh yang ditakuti lawan-lawannya.

Wilayah Buleleng Kota yang meliputi wilayah Kecamatan Buleleng dipimpin oleh I Ketut Artja selaku Kepala Staf Komando Wilayah Kota. Dengan demikian kasus penumpasan PKI di wilayah kota maupun desa-desa yang ada di Kecamatan Buleleng termasuk di Desa Penglatan merupakan tanggung jawab dari I Ketut Artja. Wilayah Buleleng Selatan yang meliputi seluruh desa-desa yang berada di wilayah Kecamatan Sukasada dipimpin oleh I Ketut Sumidra sebagai Kepala Staf Komando. Di wilayah Buleleng Barat yang meliputi Banjar, Seririt dan Gerokgak pelaksanaannya dipimpin oleh Putu Dana. Masing-masing Kepala Staf bertanggung jawab pada wilayah kerjanya. Dalam menjalankan penumpasannya, PNI bersama-sama front Marhaenis di wilayahnya dan RPKAD serta dukungan massa secara spontan dan sukarela melakukan penumpasan.

Tokoh-tokoh PNI di Desa Penglatan berusaha supaya kasus pembunuhan 
terhadap anggota PKI tidak berkembang, sehingga banyak tokoh PKI yang bisa selamat dari upaya eksekusi, tokoh-tokoh PNI yang dimaksud adalah Gusti Putu Teken, Nengah Sadra, Wayan Siden, Nyoman dayuh, Putu Suwindra, Nyoman Gede. Tokoh-tokoh PNI terutama di Banjar Kelodan mengamankan tokoh-tokoh PKI antara lain Pan Kayun, Widra, Loka, Ketut Jimat, Joreng, Pan Natih, Mudana, Oka, Japa, Linggih, dan Santya. Tokoh-toh PKI yang diamankan selamat karena mendapat perlindungan dari tokoh-tokoh PNI.

IV. PENUTUP

\section{A. SIMPULAN}

1. latar belakang peristiwa tragedi kemanusiaan pasca peristiwa Gerakan 30 September 1965 di Desa Penglatan adalah 1). Adanya persaingan politik, persaingan tersebut berakar dari persaingan antara $\mathrm{PNI}$ dan $\mathrm{PKI}, 2)$. Persaingan ekonomi antara masyarakat yang tergabung dalam PNI dan PKI

2. Para pemuda PNI yang tergabung dalam Gerakan Siswa Nasional Indonesia (GSNI), PETANI (Persatuan Petani Nasional Indonesia), LKN (Lembaga Kebudayaan Nasional), Gerakan Pendidik Marhaenis, Gerakan Pemuda Demokrat secara aktif ikut dalam usaha-usaha pendataan anggota-anggota PKI yang terganung dalam BTI dan Lekra maupun Pemuda Rakyat. Anggota PKI di Desa Penglatan tidak mengadakan perlawanan ketika dijemput oleh pasukan Tameng
Marhaenis. Korban di Desa Penglatan terbanyak di Banjar Kajanan sejumlah 17 orang yang di eksekusi seme Dalem Alit dan Banjar Kelodan 3 orang yang dieksekusi di seme Banjar Kelodan

3. Implikasi tragedi kemanusiaan anggota PKI adalah Keluarga-keluarga kehilangan tulang punggung keluarga, dan dirasakan dampaknya secara ekonomi.Keluarga yang ditinggal juga mendapat sanksi sosial dari masyarakat di lingkungan desa, mereka dicap sebagai keturunan PKI, setiap aktivitas mereka selalu mendapat pengawasan dari aparat warga, aparat desa dan pihak berwajib. Dalam pelayanan administrasi pasca peristiwa G 30 September 1965, merekapun mendapatkan perlakuan diskriminatif, seperti adanya kode ET, yang berarti eks tahanan politik

4. Aspek-aspek dari tragedi kemanusiaan pasca peristiwa Gerakan 30 September 1965 di Desa Penglatan 1) Aspek Historis, yang dapat dijadikan sebagai sumber belajar sejarah kontemporer, 2). Kolaborasi Pembunuhan Anggota PKI yang melibatkan Pepelrada Bali Pangdam XVI/Udayana, mengeluarkan keputusan pada tanggal 24 November 1965 tentang pedoman untuk menumpas G 30 S/PKI dan kewenangan TIM Pemerintah Daerah (Teperda) dalam memeriksa oknumoknum yang terlibat G 30 S/PKI

\section{DAFTAR PUSTAKA}

Alwasilah, A.C. 2002. Pokok Kualitatif Dasar-dasar Merancang dan Melakukan Penelitian Kualitatif. Jakarta: Pustaka Jaya

Astrid Susanto.2006.Pengantar Sosiologi Dan Perubahan Sosial.Bandung:Bina Cipta. Atmadja. Nengah Bawa. 2014. Saraswati dan Ganesha Sebagai Simbol Paradigma Interpretativisme dan Positivisme Visi Integral Mewujudkan Iptek dari Pembawa 
Musibah Menjadi Berkah bagi Umat Manusia. Denpasar: Pustaka Larasan. Baskara. T Wardaya. 2014 Luka Bangsa Luka Kita Pelanggaran HAM Masa Lalu dan Tawaran Rekonsiliasi. Yogyakarta: Galang Pustaka.

Budi Susanto. 2003. Politik \& Poskolonialitas di Indonesia. Yogyakarta: Kanisius Budiasih, Ni Luh. 1992. "Partai nasional Indonesia di Buleleng (1950-1973)"(Skripsi) pada Jurusan Sejarah Fakultas Sastra Universitas Udayana

Degung Santikarma. 2013. Menulis Sejarah dan Membaca Kuasa: Politik pasca-1965 di Bali dalamPerpektif Baru Penulisan Sejarah Indonesia. Henk Schulte Nordholt, Bambang Purwanto, Ratna Saptari (Ed). Jakarta: Yayasan Obor Indonesia

Deliar Noer. 2000., Pemikiran Politik Di Negeri Barat, Bandung : Mizan.

Dom Helder Camara.2000. Spiral Kekerasan,Yogyakarta : Insist, Pustaka Pelajar.

Dwipayana dan Nazaruddin Syamsuddin. 1991. Jejak Langkah Pak Harto 1 Oktober 1965-27 Maret 1968. Jakarta: Citra Lamtoro Gung Sejahtera.

Elly M. Setiadi dan Usman Kolip.2011. Pengantar Sosiologi Pemahaman Fakta dan GejalaPermasalahan Sosial: Teori, Aplikasi, dan Pemecahannya.Jakarta: Kencana Prenada Media Group

Frans Husken. 2003. Orde Zonder Order Kekerasan dan Dendam di Indonesia 19651998. Yogyakarta: LkiS

Geertz, Hildred. 1991. " A Theatre of Cruelty: The Contexs of a Topeng Performance". Dalam Hilred Geertz (ed.). State and Society in Bali. Leiden: KTTLV Press

Ignas Cleden. 1998. Paham kebudayaan Clifford Geertz. Jakarta: LP3ES

Irving M. Zeitlin.1998.Memahami Kembali Sosiologi.Yogyakarta: Gajah Mada University Press

J. Dwi Narwoko dan Bagong Suyanto.2005. Sosiologi Teks Pengantar dan Terapan, Jakarta: Kencana Prenada Media Group

John Galtung. 2002. Kekerasan Kultural dalam Wacana Kekerasan (Dalam Masyarakat Transisi). Yogyakarta: Insist

Joko Suryo, 2000. "Mengungkap Gejala Kekerasan dalam Sejarah Manusia", dalam Yayah Khisbiyah (ed), Melawan Kekerasan Tanpa Kekerasan, Yogyakarta : Pustaka Pelajar.

Julius Pour. 2010. Gerakan 30 September Pelaku, Pahlawan \& Petualang. Jakarta: Kompas

Jusuf Wanandi. 2014. Menyibak Tabir Orde Baru Memoar Politik Indonesia 19651998. Jakarta : Kompas

Kamus Besar Bahasa Indonesia.2005.Jakarta: Balai Pustaka

Karwono, 2007. "Pemanfaatan Sumber Belajar dalam Upaya Peningkatan Kualitas dan Hasil Belajar". Makalah. FKIP Universitas Muhhmadiyah

Kusnadi.2002. Masalah Kerja Sama, Kekerasan dan Kinerja. Malang : Taroda.

Majid, Abdul. 2007 . Perencanaan Pembelajaran . Bandung: PT Remaja Rosdakarya Miles, M.B dan A.M. Hubermen. 1992. Analisis Data Kualitatif Buku Sumber tentang Metode-metode Baru. (Tjetjep Rohendi Rohidi Penerjemah). Jakarta: UI Press.

Moedjanto G.1993. Indonesia Abad Ke-20 (Dari Kebangkitan Nasional Sampai Linggajati). Yogyakarta :Kanisius. 
Nana, Sudjana,dkk. 2001. Dasar-Dasar Proses Belajar Mengajar. Bandung: Sinar Baru Algensindo

Nasikun.2003. Sistem Sosial Indonesia. Jakarta: PT. Raja Grafindo Persada.

Rex Mintimer. 1969. Class, Social Cleveage and Indonesia Communism. Dalam Indonesia, No. 8 , Oktober, 1969.

Robert H. Lauer.2001. Perspektif Tentang Perubahan Sosial. Jakarta : PT. Rineka Cipta.

Robert lawang1994. Buku Materi Pokok Pengantar Sosiologi. Jakarta: Universitas Terbuka.

Sanjaya, Wina. 2008. Strategi Pembelajaran Berorientasi Standar Proses Pendidikan. Jakarta: Kencana

Sardiman, A.M. 2001, 2005. Interaksi dan Motivasi Belajar Mengajar .Jakarta: Raja Grafindo

Sing, T.D. 2007. Kehidupan dan Evolusi Spiritual. Made Wardhana (Penerjemah). Denpasar: Yayasan Institut Bhaktivedanta Indonesia.

Soerjono Soekanto.1992. Sosiologi Suatu Pengantar. Jakarta: Rajawali Pers.

Soerjono Soekanto.1993. Kamus Sosiologi.Jakarta: PT. Raja Grafindo Persada

Soetomo.1995. Masalah Sosial dan Pembangunan. Jakarta: PT. Dunia Pustaka Jaya, Suryawan. 2007. Ladang Hitam di Pulau Dewata: Pembantaian Massal 1965 di Bali. Yogyakarta: Galang Press

Thomas Santoso, 2000. Teori-Teori Kekerasan, Jakarta: Ghalia Indonesia, Vickers, Adrian. 1989. Bali: A Paradise Created. Singapura: Periplus Edition Wiana. 2007. Tri Hita Karana Menurut Konsep Hindu. Surabaya: Paramitha

Widja. 1996. Permasalahan Metodologi Dalam Pengajaran Sejarah di Indonesia Suatu Tinjauan Reflektif Dalam Mengatasi Perkembangan Abad XXI Dalam Konggres Nasional Sejarah. Jakarta: Depdikbud.

Yahya A. Muhaimin. 2005. Perkembangan Militer Dalam Politik di Indonesia 19451966. Yogyakarta: gajah Mada University Press 